\title{
PERAWATAN PERIANAL DENGAN BABY OIL MENURUNKAN KEJADIAN DIAPER DERMATITIS PADA NEONATUS DI RUANG NEONATUS RSUD SIDOARJO
}

\author{
Navi Fitrothul Chasanah, Farida Umamah \\ UNUSA, FIK, Prodi SI Kep[erawatan - Jl Smea 57 Surabaya \\ Email : umamahfarida@yahoo.com
}

\begin{abstract}
The Influence of Perianal Care with Baby Oil in Order to Prevent Diaper Dermatitis on Neonates in Neonates Room of RSUD Sidoarjo. The purpose of this research is to know the effect of perianal care with baby oil in order to prevent diaper dermatitis on neonates in neonates room of RSUD Sidoarjo. Quasy experiment was used in designing this study. The population were all babies hospitalized in neonates room of RSUD Sidoarjo. Size of sample was 20 respondents fulflling inclusion criteria. Sample is collected by using purposive sampling technique. Independent variable in this research was the method of perianal care with baby oil and dependent variable was incidence of diaper dermatitis in neonates. Used instrument is check list and structured observation. Then the data was analyzed by using Mann Whitney statistic test. From the research, all pretest score is good both on experiment group and control group with condition of normal skin is $100 \%$. Meanwhile posttest score on experiment group with condition of normal skin is $90 \%$ and on control group with condition of normal skin is $50 \%$ but almost a half of them (40\%) suffer mild diaper dermatitis. From the result of statistic test it shows that $\rho=0,045<\alpha=0,05$. The conclusion of this research is that routine perianal care with baby oil before wearing diaper after urination and defecation is effective to prevent diaper dermatitis incident in neonates. To prevent diaper dermatitis can be done with perianal care use baby oil routinely.
\end{abstract}

\begin{abstract}
Abstrak : Pengaruh Perawatan Perianal dengan Baby oil terhadap Pencegahan Diaper dermatitis pada Neonatus Diruang Neonatus RSUD Sidoarjo. Tujuan penelitian adalah untuk mengetahui pengaruh perawatan perianal dengan baby oil terhadap pencegahan diaper dermatitis pada neonatus di ruang neonatus RSUD Sidoarjo. Desain penelitian ini menggunakan desain quasy eksperiment. Populasinya adalah seluruh bayi yang dirawat di ruang neonatus RSUD Sidoarjo. Besar sampel sebanyak 20 responden yang sesuai dengan kriteria inklusi. Sampel diambil dengan tehnik purposive sampling. Variabel independen pada penelitian ini adalah metode perawatan perianal dengan baby oil dan variabel dependennya adalah kejadian diaper dermatitis. Instrumen yang digunakan berupa check list dan lembar observasi. Data dianalisa dengan menggunakan uji statistik dengan Mann Whitney. Hasil penelitian didapatkan nilai pretest baik untuk kelompok eksperimen maupun kelompok kontrol seluruhnya dengan kondisi kulit normal (100\%), sedangkan pada nilai posttest untuk kelompok eksperimen hampir seluruhnya dengan kondisi kulit normal (90\%) dan untuk kelompok kontrol setengahnya (50\%) dengan kondisi kulit normal, namun hampir setengahnya juga terkena diaper dermtitis ringan (40\%). Didapatkan hasil uji statistik nilai $\rho$ $(0,045)<\alpha(0,05)$. Simpulan dari penelitian ini adalah perawatan perianal menggunakan baby oil secara rutin sebelum memakaikan bayi popok, baik setelah BAK maupun BAB terbukti efektif untuk mencegah terjadinya diaper dermatitis pada neonatus. Untuk mencegah diaper dermatitis dapat dilakukan dengan perawatan perianal menggunakan baby oil secara rutin.
\end{abstract}

Kata kunci : perawatan perianal, baby oil, diaper dermatitis 


\section{PENDAHULUAN}

Neonatus memiliki permasalahan yang luas dan kompleks, terutama masalah kulit. Semua bayi memiliki kulit yang sangat peka dalam bulan-bulan pertama. Kondisi kulit pada bayi yang relatif lebih tipis menyebabkan bayi lebih rentan terhadap infeksi, iritasi dan alergi. Secara struktural dapat pula di lihat bahwa kulit pada bayi belum berkembang dan berfungsi optimal. Salah satu masalah kulit yang masih sering terjadi pada bayi dan anak adalah diaper dermatitis. Diaper dermatitis adalah kelainan peradangan kulit di daerah yang tertutup popok yang paling sering diderita oleh bayi atau anakanak (Maya D, 2004).

Menurut data yang didapat peneliti pada tanggal 11 Februari 2010 di ruang neonatus RSUD Sidoarjo menunjukkan bahwa, terdapat 622 (26\%) dari 2394 bayi terserang diaper dermatitis pada tahun 2007, dan pada tahun 2008 didapatkan kurang lebih 897 bayi (37\%) yang menderita diaper dermatitis dari 2425 bayi yang dirawat di ruang tersebut, serta terdapat sekitar 945 bayi (40\%) dari 2364 bayi yang dirawat di ruang tersebut menderita diaper dermatitis pada tahun 2009, disamping itu dalam satu bulan terakhir, yaitu tanggal 1 Juni sampai 30 Juni 2010, dari 174 bayi yang dirawat di ruang neonatus RSUD Sidoarjo, terdapat 47 bayi $(27 \%)$ menderita diaper dermatitis. Diaper dermatitis masuk dalam peringkat 15 besar penyakit kulit yang sering terjadi pada anak - anak di Poli Klinik Kulit Anak RSUD Kabupaten Sidoarjo periode 2007 - 2009, dimana terdapat sekitar $35 \%$ anak terkena diaper dermatitis pada usia 1 tahun pertama.

Banyak faktor yang dapat menyebabkan diaper dermatitis, diantaranya ; karena faktor paparan (urine) kencing, (feses) kotoran bayi yang berkepanjangan dan juga dapat disebabkan oleh tekanan dan gesekan diaper. Diaper dermatitis ini muncul karena seringnya kulit basah oleh keringat, urine, dan feses bayi, sehingga hal ini akan memudahkan kulit mendapat gesekan dari bahan diaper, dan akhirnya kulit menjadi iritasi. Terjadinya iritasi tersebut disebabkan karena peningkatan $\mathrm{pH}$ kulit oleh amonia urine dan aktifasi protase serta lipase dari feses bayi yang bersifat alkali (Merenstein et all, 2001).

Diaper Dermatitis atau Ruam popok adalah kelainan kulit yang timbul akibat terjadinya radang dibagian tubuh yang tertutup popok. Umumnya, penyakit ini timbul pada lipatan - lipatan kulit paha, diantara kedua pantat, dan dapat timbul dibagian kulit lainnya. Bagian yang tertutup popok mudah mengalami peradangan karena kulit menjadi hangat dan lembab serta peka terhadap bakteri dan senyawa yang dapat mengiritasinya (Soepardan dan Widyani, 2001). Diaper dermatitis dibagi menjadi tiga derajat, mulai dari ringan, sedang, sampai berat. Dampak dari dermatitis adalah bayi rewel, cemas, dan menangis sehingga membuat bayi tidak mau menetek ke ibu dan bayi tidak bisa tidur, yang akibatnya membuat berat badan bayi turun. Bila sudah dalam keadaan demikian bayi harus mendapat perawatan intensif.

Perawatan perianal dengan menggunakan baby oil, kulit bayi terjaga tetap kering, ammonia dan enzim fecal tidak mudah meresap dalam kulit bayi sehingga permeabilitas kulit ( $\mathrm{pH}$ kulit) normal (Sujayanto, 2001).

Cumberlandswand

mengatakan bahwa perawatan perianal dengan menggunakan baby oil dapat menurunkan kejadian diaper dermatitis, karena baby oil memiliki efek perawatan yang baik. Di dalam baby oil terdapat proporsi asam lemak tak jenuh yang tinggi yang di dalamnya mengandung bahanbahan diantaranya gliserin, tocopherylacetate (vitamin E), chamomile extract dan zink oxid. Pencegahan diaper dematitis dapat dilakukan dengan cara membersihkan sebaik mungkin daerah yang tertutup popok setelah bayi kencing atau buang air besar dengan baby oil, 
sehingga pemberian baby oil ke bokong dapat bermanfaat untuk mencegah amonia menempel di kulit dan untuk mempermudah mengangkat mekonium.

\section{METODE}

Desain atau rancang bangun pada penelitian ini adalah Quasy Eksperiment pre post test design. Populasi dalam penelitian ini adalah bayi yang dirawat di ruang Neonatus RSUD Sidoarjo. Sampel dalam penelitian ini adalah bayi yang di rawat di ruang neonatus RSUD Sidoarjo sebanyak 20 bayi sesuai dengan criteria inklusi, yaitu 10 bayi untuk kelompok intervensi dan 10 bayi untuk kelompok kontrol. Pada penelitian ini peneliti menggunakan Non Probability Sampling (purposive sampling). Variabel independen pada penelitian ini adalah metode perawatan perianal dengan baby oil sedangkan variabel dependen pada penelitian ini adalah kejadian diaper dermatitis.

Data yang telah terkumpul kemudian ditabulasi dan diolah dengan uji statistik Mann Whitney yaitu test untuk menguji hipotesis komparatif satu sampel independen bila datanya berbentuk ordinal dengan tingkat kemaknaan $\alpha \leq 0,05$. Artinya apabila $\rho<0,05$ maka $\mathrm{H} 0$ ditolak yang berarti ada perbedaan yang bermakna antara perawatan perianal pada kelompok eksperimen (baby oil) dengan kelompok kontrol (air bersih) terhadap pencegahan diaper dermatitis pada neonatus. Analisis ini menggunakan perangkat lunak komputer.

\section{HASIL DAN PEMBAHASAN}

Kondisi Kulit Bayi Saat Pretest Dan Posttest Terhadap Kejadian Diaper Dermatitis.

Tabel 1 Distribusi responden berdasarkan kondisi kulit bayi pada saat pretest dan posttest yang dirawat di ruang Neonatus RSUD Kabupaten Sidoarjo Tahun 2011

\begin{tabular}{|c|c|c|c|c|}
\hline \multirow{2}{*}{ Kondisi Kulit } & \multicolumn{2}{|c|}{ Pretest } & \multicolumn{2}{|c|}{ Posttest } \\
\hline & $\mathrm{F}$ & $(\%)$ & $\mathrm{F}$ & (\%) \\
\hline & \multicolumn{4}{|c|}{ Kelompok eksperimen } \\
\hline Normal & 10 & 100 & 9 & 90 \\
\hline $\begin{array}{l}\text { Diaper } \\
\text { dermatitis } \\
\text { Ringan } \\
\end{array}$ & 0 & 0 & 1 & 10 \\
\hline $\begin{array}{l}\text { Diaper } \\
\text { dermatitis } \\
\text { Sedang }\end{array}$ & 0 & 0 & 0 & 0 \\
\hline $\begin{array}{l}\text { Diaper } \\
\text { dermatitis } \\
\text { Berat }\end{array}$ & 0 & 0 & 0 & 0 \\
\hline \multirow[t]{2}{*}{ Total } & 10 & 100 & 10 & 100 \\
\hline & \multicolumn{4}{|c|}{ Kelompok kontrol } \\
\hline Normal & 10 & 100 & 5 & 50 \\
\hline $\begin{array}{l}\text { Diaper } \\
\text { dermatitis } \\
\text { Ringan }\end{array}$ & 0 & 0 & 4 & 40 \\
\hline
\end{tabular}

Tabel 1 dapat dilihat bahwa kondisi kulit bayi pada saat pretest baik untuk kelompok eksperimen maupun kelompok kontrol seluruhnya normal (100\%). Dan dari hasil observasi kondisi kulit bayi pada saat posttest untuk kelompok eksperimen menunjukkan bahwa hampir seluruhnya bayi dengan kondisi kulit normal (90\%), sedangkan untuk kelompok kontrol didapatkan hasil yaitu setengahnya dengan kondisi kulit bayi normal $(50 \%)$ dan hampir setengahnya terkena diaper dermatitis ringan $(40 \%)$.

Tabel 2. Pengaruh perawatan perianal pada kelompok eksperimen (baby oil) dengan kelompok kontrol (air bersih) terhadap pencegahan diaper dermatitis pada neonatus di ruang neonatus RSUD Sidoarjo tahun 2011 


\begin{tabular}{|c|c|c|c|c|c|c|c|c|c|c|}
\hline \multirow{3}{*}{$\begin{array}{c}\text { Pera } \\
\text { wata } \\
\text { n } \\
\text { Peri } \\
\text { anal }\end{array}$} & \multicolumn{8}{|c|}{ Kondisi Kulit } & \multirow{2}{*}{\multicolumn{2}{|c|}{ Total }} \\
\hline & \multicolumn{2}{|c|}{ Normal } & \multicolumn{2}{|c|}{ Ringan } & \multicolumn{2}{|c|}{ Sedang } & \multicolumn{2}{|c|}{ Berat } & & \\
\hline & $\mathrm{F}$ & $\%$ & $\mathrm{~F}$ & $\%$ & $\mathrm{~F}$ & $\%$ & $\mathrm{~F}$ & $\%$ & $\mathrm{~F}$ & $\%$ \\
\hline $\begin{array}{l}\text { Eksp } \\
\text { erim } \\
\text { en }\end{array}$ & 9 & 90 & 1 & 10 & 0 & 0 & 0 & 0 & $\begin{array}{l}1 \\
0\end{array}$ & 100 \\
\hline $\begin{array}{l}\text { Kont } \\
\text { rol }\end{array}$ & 5 & 50 & 4 & 40 & 1 & 10 & 0 & 0 & $\begin{array}{l}1 \\
0\end{array}$ & 100 \\
\hline $\begin{array}{l}\text { Tota } \\
1\end{array}$ & $\begin{array}{l}1 \\
4\end{array}$ & 70 & 5 & 25 & 1 & 5 & 0 & 0 & $\begin{array}{l}2 \\
0\end{array}$ & 100 \\
\hline
\end{tabular}

Berdasar tabel 2 dapat dilihat bahwa dari 10 responden yang merupakan kelompok eksperimen (perawatan perianal dengan baby oil), hampir seluruhnya (90\%) dengan kondisi kulit yang normal. Sedangkan 10 responden untuk kelompok kontrol, terdapat setengahnya (50\%) dengan kondisi kulit normal, namun hampir setengahnya juga mengalami diaper dermatitis ringan (40\%).

Pengaruh antara kelompok eksperimen (perawatan perianal dengan baby oil) dengan kelompok kontrol (perawatan perianal dengan air bersih) terhadap pencegahan diaper dermatitis, dapat digunakan uji Mann-Whitney. Pada proses perhitungan Mann-Whitney menggunakan uji SPSS didapatkan nilai $\rho$ $=0,045$ dan $\alpha=0,05$, berarti $\rho<\alpha$ maka $\mathrm{H}_{1}$ diterima berarti ada pengaruh antara perawatan perianal pada kelompok eksperimen (baby oil) dengan kelompok kontrol (air bersih) terhadap pencegahan diaper dermatitis pada Neonatus.

\section{PEMBAHASAN}

1. Kejadian Diaper Dermatitis Sebelum Perawatan Perianal Dengan Baby Oil.

Hasil observasi pada penelitian ini menunjukkan bahwa kondisi kulit pada bayi sebelum dilakukan perawatan perianal dengan baby oil seluruhnya normal . Hal ini dapat disebabkan oleh banyak hal misalnya, seluruh bayi yang menjadi responden pada penelitian ini memiliki berat badan yang normal yaitu berkisar antara 2,5 - 3,8 $\mathrm{kg}$ dan dilahirkan cukup bulan (aterm), bayi yang dilahirkan cukup bulan akan memiliki jaringan kulit yang lebih sempurna dibandingkan bayi yang lahir kurang bulan.

Berkaitan dengan anatomi dan fisiologi dari kulit, kulit pada bayi relatif tipis, dan mempunyai suatu kandungan air yang tinggi pada lapisan dalam dan fungsi perlindungan yang belum berkembang dengan penuh perlindungan melalui sebum seperti pada kulit remaja masih belum bisa. Kondisi kulit bayi baru lahir mengalami peralihan dari lingkungan dalam kandungan terhadap perubahan suhu dengan kelembaban udara yang berubahubah dan juga kontak dengan kuman, patogen, substansi yang berbahaya sehingga berpotensi mendapat mengganggu kulit bayi setelah kelahiran (Sujayanto, 2001).

2. Kejadian Diaper Dermatitis Sesudah Perawatan Perianal Dengan Baby Oil.

Pada kelompok eksperimen, setelah bayi dilakukan perawatan perianal dengan baby oil, hampir seluruhnya masih menunjukkan kondisi kulit yang normal hal ini dapat disebabkan karena baby oil memiliki efek perawatan yang baik, dimana di dalam baby oil terdapat proporsi asam lemak tak jenuh yang tinggi yang di dalamnya mengandung beberapa bahan.

Bahan tersebut diantaranya gliserin, tocopherylacetate (vitamin E), chamomile extract dan zink oxid yang sangat bermanfaat bagi kulit. Bayi yang diberi perawatan perianal dengan baby oil kulitnya akan terjaga tetap kering sehingga $\mathrm{pH}$ kulit bayi akan tetap normal dan untuk 1 bayi (10\%) lainnya pada kelompok eksperimen, menunjukkan bahwa bayi tersebut terkena diaper dermatitis ringan, hal ini dapat disebabkan karena berbagai macam hal, misalnya kondisi kulit bayi yang terlalu sensitif, disamping itu dari data yang didapatkan peneliti, responden yang mengalami diaper dermatitis ringan pada kelompok eksperimen tersebut 
menunjukkan bahwa responden tersebut masih berusia 1 hari, dimana semua bayi pada minggu - minggu pertama kelahiran memiliki kulit yang sangat peka. Kondisi kulit pada bayi yang relatif lebih tipis menyebabkan bayi lebih rentan terhadap infeksi, iritasi dan alergi. Secara struktural dapat pula di lihat bahwa kulit pada bayi belum berkembang dan berfungsi optimal.

Kelompok kontrol yang hanya dilakukan perawatan perianal dengan air bersih ditemukan lebih banyak bayi yang terkena diaper dermatitis ringan dibandingkan pada kelompok eksperimen, yaitu sebanyak 4 bayi . Diaper dermatitis ringan tersebut kemungkinan dapat disebabkan karena terlalu lembabnya kulit bayi setelah terjadinya gesekan yang berlebihan antara kulit bayi dengan bahan popok karena seringnya bayi mengganti popok ketika BAB dan BAK. Air bersih biasa tidak memiliki kandungan seperti baby oil yang dapat mencegah kelembaban yang berlebihan pada kulit bayi sehingga kulit bayi akan lebih mudah iritasi.

Menurut Maya Devinta (2004), banyak faktor yang menyebabkan terjadinya diaper dermatitis. Diantaranya faktor fisik (pakaian dan popok), faktor kimiawi (bahan kimia dalam urine dan feces), faktor enzimatik (bahan kimia yang bereaksi secara enzim) dan adanya mikroba (jamur dan bakteri pada urine dan feces yang terdapat dalam popok. Enzimenzim fecal yang terdapat dalam feces bayi merupakan bahan iritan yang dapat meningkatkan permeabilitas kulit bayi. Didalam urine juga terdapat berbagai organisme diantaranya bacterium amoniagenes yang dapat mengubah urea menjadi ammonia. Amonia dapat meningkatkan $\mathrm{pH}$ pada permukaan kulit bayi sehingga kulit lebih mudah terjadi iritasi.

3. Pengaruh Perawatan Perianal Dengan Baby Oil Terhadap Pencegahan Diaper dermatitis Pada Neonatus. Berdasarkan hasil statistik dengan menggunakan Uji Mann Whitney didapatkan hasil nilai signifikan sebesar ( $\rho$ $0,045<\alpha$ 0,05). Hal ini berarti ada pengaruh penggunaan baby oil pada perawatan perianal terhadap pencegahan diaper dermatitis. Dapat dilihat di Tabel 5.8 menunjukkan bahwa yang mengalami penyakit diaper dermatitis pada kelompok eksperimen (10\%) lebih sedikit dibandingkan dengan yang normal (90\%).

Perawatan perianal dengan menggunakan baby oil, kulit bayi terjaga tetap kering, ammonia dan enzim fecal tidak mudah meresap dalam kulit bayi sehingga permeabilitas kulit ( $\mathrm{pH}$ kulit) normal. Sedangkan jika pada perawatan perianal dengan air bersih, kulit bayi menjadi lembab oleh urine dan feces, enzim-enzim fecal yang terdapat dalam feces bayi merupakan bahan iritan yang dapat meningkatkan permeabilitas kulit bayi, sehingga memudahkan kulit bayi iritasi (Sujayanto, 2001).

Menurut Cumberlandswand (2003) perawatan perianal dengan menggunakan baby oil dapat menurunkan kejadian diaper dermatitis, karena baby oil memiliki efek perawatan yang baik. Baby oil yang dianggap memiliki efek perawatan yang baik adalah minyak dengan proporsi asam lemak tak jenuh yang tinggi yang didalamnya mengandung gliserin, tocopherylacetate, vitamin $E$, chamomile extract dan zink oxid.

\section{A. SIMPULAN}

1. Kondisi kulit bayi sebelum perawatan perianal dengan baby oil baik untuk kelompok eksperimen maupun kelompok kontrol seluruhnya normal (kulit berwarna pink pale) dan tidak mengalami Diaper Dermatitis.

2. Kondisi kulit bayi sesudah perawatan perianal dengan baby oil dan diamati selama 2 hari, dimana pada kelompok eksperimen didapatkan hasil bahwa hampir seluruhnya bayi dengan kondisi kulit yang normal. Sedangkan pada kelompok kontrol yang hanya diberikan perawatan perianal dengan 
air biasa menunjukkan hasil bahwa setengahnya dari jumlah bayi dengan kondisi kulit normal dan hampir setengahnya mengalami diaper dermatitis ringan.

3. Ada pengaruh penggunaan baby oil pada perawatan perianal terhadap pencegahan diaper dermatitis.

\section{DAFTAR PUSTAKA}

Cumberlandswand (2003). Baby Oil Products. www. Babycare.com. Artikel diakses tanggal 08 Februari 2011, pukul 13.00 WIB.

Darsana (2009). EfektivitasPerawatan Perianal. www. Darsanursejiwa.com. Artikel diakses 22 februari, pukul 12.47 WIB.

Defka (2010). Asuhan Keperawatan Ruam Popok. www: defkanurse. Wordpress.com. Artikel diakses tanggal 10 Februari 2011, pukul $12.00 \mathrm{WIB}$.

Irwan (2008). Popok Bayi. www. dokteranakku.com. Artikel diakses tanggal 15 Februari 2011, pukul $16.50 \mathrm{WIB}$.

Ladewig, Patricia et all (2006). Buku Saku Asuhan Ibu dan Bayi Baru Lahir Ed.5. Jakarta, EGC. Hal. 153, 158.

Lestari, Titi (2003). Pengobatan Kombinasi Mitoconazol Nitrat dan Seng pada Dermatitis Popok. www: tempo.co.id. Artikel diakses tanggal 08 Februari 2011, pukul 13.45 WIB.

Manulung, Yessi (2010). Pengetahuan Dan Tindakan Ibu Dalam Perawatan Perianal Pada Neonatus. Www. researchgate.net/publication.com.
Artikel diakses tanggal 16 Februari 2011, pukul 12.20 WIB.

Maya Devita (2004). Popok Bayi Bisa Menjadi Sumber Penyakit. www. Infokes.Com. Artikel diakses tanggal 13 Februari 2011, pukul 18.15 WIB.

Merenstein, Gerald B., Kaplan, David W., Rosenberg, Adam A. (2001). Buku Pegangan Pediatri. Jakarta, Widya Medika. Hal. 411, 412.

Nursalam (2008). Konsep dan Penerapan Metodologi Penelitian Ilmu Keperawatan. Jakarta, Salemba Raya. Hal 86, 89, 92, 93, 97, 111

Nursalam (2003). Konsep dan Penerapan Metodologi Penelitian Ilmu Keperawatan. Jakarta, Salemba Raya. Hal 85,96,111.

Notoatmodjo, Soekidjo (2005). Metodologi Penelitian Kesehatan. Jakarta, PT Rineka Cipta. Hal 194.

Schartz, William, M. (2004). Pedoman

Steven (2010). Trends, Tips, and Solution Parenting. www. conetique.com. Artikel diakses tanggal 28 februari, pukul 09.59 WIB.

Widia, Alina (2009). Kulit Bayi. www. wordpress.com. Artikel diakses tanggal 15 Mei 2011, pukul 20.08 WIB.

ZR, Arief, Kristyanasari, Weni (2009). Neonatus dan Asuhan Keperawatan Anak. Yogyakarta, NUHA Medika. Hal. 81, 82. 